\title{
Brexodus and the Commercial Real Estate Markets of London and Paris
}

Brexodus et les marches immobiliers commerciaux de Londres et de Paris

\section{Susan Ball}

\section{CpenEdition}

\section{Journals}

Electronic version

URL: https://journals.openedition.org/rfcb/8925

ISSN: 2429-4373

\section{Publisher}

CRECIB - Centre de recherche et d'études en civilisation britannique

\section{Electronic reference}

Susan Ball, "Brexodus and the Commercial Real Estate Markets of London and Paris", Revue Française de Civilisation Britannique [Online], XXVII-1 | 2022, Online since 04 January 2022, connection on 01 February 2022. URL: http://journals.openedition.org/rfcb/8925

This text was automatically generated on 1 February 2022.

\section{(i) $\odot$

Revue française de civilisation britannique est mis à disposition selon les termes de la licence Creative Commons Attribution - Pas d'Utilisation Commerciale - Pas de Modification 4.0 International. 


\title{
Brexodus and the Commercial Real Estate Markets of London and Paris
}

\author{
Brexodus et les marches immobiliers commerciaux de Londres et de Paris
}

\author{
Susan Ball
}

Acknowledgements: The author would like to thank the two anonymous peer reviewers for helpful comments and suggestions, and the editors of this special edition of RFCB.

\section{Introduction}

Since 2015, and the announcement of a possible EU referendum, there has been much speculation about the number of jobs London could lose to Paris and other European capitals (Brexodus). Defacto, the company that manages La Défense, was quick to recognise the potential of London-to-Paris relocations with its 2016 marketing campaign 'Tired of the fog? Try the frogs!'; while the President of the Regional Council of Île-de-France - Valérie Pécresse - stated her aim to bring 10,000 jobs from London to the region by 2019. In the context of a global real estate market, there was speculation that the loss of jobs by London to Paris could go beyond direct transfers to include those of non-European firms considering locating in Europe and which may no longer view London as the 'obvious choice'. Less commented upon was the interconnected nature of property finance and development in global cities, such that job transfers by office occupiers in London's banking sector would in time impact on employment in development finance and investment, construction and a wide range of supporting services. It is not therefore surprising that campaigns to attract jobs to Paris were met by a response from London, with Mayor Sadiq Khan launching \#LondonIsOpen in January 2017. But what really is at stake here? Is it a case of Paris versus London as world financial centres, or are both cities part of a wider office market for which Brexit is but one more variable to be factored into the calculation of risk over the short- and long-term? Following speculation about losses and gains, the prognosis seems to have settled on the relocation from London of some departments rather than whole headquarters. If job postings for employment in banking are a reliable forward-looking 
indicator, then "it really isn't a tsunami of hires", with banks in London making only "modest tweaks" in a climate of uncertainty. ${ }^{1}$

Brexodus or not, the UK's withdrawal from the EU involves the negotiation of boundaries for the circulation of people, goods and capital as part of ongoing processes of bordering ${ }^{2}$. At a time when global networks transcending the borders of state territories are transforming the spatial organisation of social relations and transactions, ${ }^{3}$ these processes will have implications for flows of capital within and beyond Europe. Arguably, this reorganisation is bringing regions and cities into prominence as competing legal spaces for the circulation of capital. ${ }^{4}$ London and Paris have been two outstanding winners in this race towards global-local interconnectedness. One reason for this is the role these cities' real estate investment markets have played in offering a spatial fix to crises of over accumulation. ${ }^{5}$ The uneven map of global property investment is one illustration of the working out of processes of valuation and the normative power of property investors. A key factor in assuring the success of competing real estate markets is their ability to place-make ${ }^{6}$ through the use of diverse forms of contemporary border hardening. The discourse of international firms of property consultants is one means by which these processes of valuation and the borders through which they are filtered are presented as inevitable.

3 This paper does not attempt to conduct detailed analysis of the commercial real estate markets of Paris and London as part of the global network of property finance. Rather it seeks to set out a framework for understanding the role played by firms of real estate consultants in allowing capital to circulate between the legal spaces of the property investment markets. This framework is based both on the development of an island economy of global financial centres, of which London and Paris are a part, and on research into the discourse of international glocal property consultants in the ongoing process of re-bordering and filtering of flows of finance that reflect the normative power of international real estate investors. It starts with a discussion of the evolution of cross-border consultancy relations since Big Bang in 1986 and in the context of the financialisation of real estate. The paper then goes on to examine research reports and commentaries published since the 2016 United Kingdom European Union membership referendum by the three leading firms of property consultants covering the London and Paris office markets. It provides evidence of the role played by consultants in providing a market of secure investments and in reinforcing the borders of the island economy. Finally it points to some areas for future research on the social practices underpinning the bordering of the island economy of real estate investment.

\section{The internationalisation of real estate and property consultancy: the creation of an island economy}

Prior to the Second World War most commercial and industrial property was not considered as a significant part of the investment market. The financialisation of real estate $^{7}$ in the UK was first noted by radical publications that drew attention to the growing involvement of life assurance companies and pension funds in property investment in the late 1960s. ${ }^{8}$ Spurred on by the rapid growth of flows of funds into institutions, and the latters' growing appreciation of property as an investment vehicle in a climate of rapidly rising inflation and relative economic decline, direct institutional property investment increased rapidly. In part because offices in central 
London had been the main focus of the initial post-war boom in property (1954-64), they came to be the subject of institutional investment in real estate in the late 1960 s and have since continued to occupy a dominant position. Over the same period, the interdependence between finance capital and property development deepened, leading Ambrose and Colenutt to comment in 1975 that: "it is almost impossible to draw the line between property companies, construction companies, banks, insurance companies and investment trusts," 9 which comprised a growing and complex network of actors: "construction firms, land owners and financial institutions trading in stocks and shares, government bonds, and currencies, and ... providing services such as insurance, pensions, hire purchase and mortgages". ${ }^{10}$ As finance and real estate became more closely intertwined, the power of the finance sector increased; as Ambrose and Colenutt argued: "any move which threatens (the financial institutions') interests is quickly and vigorously blocked." ${ }^{11}$ Since 1975 this sector's interests have extended beyond the central London commercial property market to the commercial property markets of large business cities abroad.

5 The main problem facing UK financial institutions in their drive to increase their property portfolios from the late 1960s was the lack of supply of real estate of investment quality (prime property). The removal of exchange controls in 1979, which had as its logical conclusion the 1986 Big Bang, ${ }^{12}$ opened up an almost unlimited stock of prime property overseas to UK investors, while also granting access to overseas investors to prime property in the UK. Real estate in the City of London (the financial district) was almost wholly domestically owned until the mid-1980s, after which crossborder capital flows of investment took levels of overseas ownership from under 10 per cent to over 50 per cent by $2011 .{ }^{13}$ Zhu and Lizieri's analysis of investments in offices between 2007 and 2016 in cities classified as 'international financial centres' found that $66 \%$ and $42 \%$ of total investments by value in London and Paris respectively were made by foreign (as opposed to domestic) investors ${ }^{14}$.

6 Cross-border flows of capital into commercial property have been widely commented on, finding one popular illustration in the Financial Times' choice of a global cityscape comprised of landmark office developments (and foregrounding the Grande Arche of La Défense and the Gherkin in the City of London) - with which to launch its 2007 advertising campaign..$^{15}$ While a considerable amount of research attention has been devoted to the flows of finance in the globalisation of real estate, far less attention has been given to the ways in which local property markets - such as those of London and Paris - are integrated into these international cross-border structures. A major concept in understanding how the internationalisation of real estate works is 'property market maturity', which forms part of the service provided by firms of property advisors.

7 Since 1986 a global service of property consultancy firms has grown out of partnerships of chartered surveyors based in London. The deregulation of financial markets led these partnerships, often referred to as the coffee houses of the West End, ${ }^{16}$ to apply a system of measures which would permit their performance as property fund managers to be assessed alongside the performance of investments in other asset classes. In addition, with the arrival of more indirect forms of investment in property, real estate investment became subject to much closer forms of scrutiny. By the 1990s these twin pressures - coupled with US firms' ambitions to expand into Europe - played a role in the takeover of many of the most prominent West End partnerships. In 1990 Cushman \& Wakefield acquired Healey \& Baker, thereby establishing the US firm's presence in Europe. In 1998 Coldwell \& Banker acquired Hillier, Parker, May \& Rowden and Richard 
Ellis to become CB Richard Ellis (CBRE). The following year Jones Lang Wootton merged with the Chicago-based LaSalle Partners Incorporated to form Jones Lang LaSalle Incorporated (JLL). The subsequent 2015 merger of Cushman \& Wakefield and DTZ ${ }^{17}$ places Cushman \&Wakefield alongside CBRE (which acquired the Insignia Financial Group in 2003) and JLL as the worlds' largest property consultancy businesses. These firms have each developed a global network, comprising a workforce of 229,000 employees (JLL 88,000, ${ }^{18}$ CBRE over 90,000, ${ }^{19}$ and Cushman \& Wakefield 51,000). ${ }^{20}$ This network includes offices in both London and Paris, from where reports - attesting to the transparency and market maturity of each of the cities - are produced by teams of professional researchers. ${ }^{21}$ Before going to examine these reports, it is first necessary to outline these firms' role in the provision of property markets which actors consider to be (relatively) mature, transparent and secure in a global investment market.

In order for a property market - such as the office market in central London or at La Défense - to be open to international investors it has to be mature. Keogh and D'Arcy argue that although the concept of maturity is complex and subjectively determined, actors use a limited range of market qualities in their value judgements on maturity. ${ }^{22}$ If these qualities are present then the actors can determine the attractiveness of property - in, for example, London or Paris - relative to other asset or real estate markets. In the context of fluctuating markets, and particularly since the 2008 financial crisis, investors attach particular importance to two market qualities in their assessment of risk: the provision of research activities and market information, and the existence of a sophisticated profession with its associated institutions and networks. It is firms of international property consultants like JLL, CBRE and Cushman \& Wakefield that set out to provide transparency and the comparability of the competing centres of a global real estate market. Drawing on professional advice backed by research, actors make investments in property that are considered to be secure. ${ }^{23}$

9 The importance of research to investment decisions in property pre-dates the 2008 financial crisis. Property booms and subsequent collapses in the early 1970 s and the beginning of the 1990s had already made the financial institutions and their advisors aware of the need for market information. In the early 1970s Hillier Parker (now CBRE) appointed Russell Schiller, arguably the inventor of property research in the commercial sector. In the decade to follow Richard Ellis (now also part of CBRE) appointed Gerald Brown, ${ }^{24}$ Debenham Tewson \& Chinnocks (now Cushman \& Wakefield) appointed Peter Evans and Jones Lang Wootton (now JLL) appointed Honor Chapman. All of these research posts were created as a means by which firms of chartered surveyors would face increased competition from management consultants and investment banks in the provision of property advice. ${ }^{25}$ Property research has since developed into a profession with its own journals, ${ }^{26}$ conferences, ${ }^{27}$ chairs and professorships, ${ }^{28}$ and society (in 2019 the membership of the Society of Property Researchers totalled just over 500). ${ }^{29}$ Although this development has been centred on the UK, the data that is collected and the analysis that is undertaken rely on local market knowledge or glocal knowledge, ${ }^{30}$ combining global and local knowledge. The importance of this to property investment has been part of the steep learning curve of property research, both within commercial firms and in research conducted in universities and research centres.

10 The globalisation of property investment involves investors balancing risk in order to construct property portfolios that are considered to be secure. Prior to the removal of 
exchange controls, investors' options were limited to domestic property. The removal of exchange controls simultaneously opened up the opportunity to access investments in mature and transparent property markets abroad, and to add locational diversity as what was at first perceived to be an additional element of security. This was an attractive option not only for investors but also for their professional advisors, who could sell their glocal knowledge when advising on investments in international financial markets at home and abroad. One means of developing glocal networks in the 1990s was for London-based firms to enter into partnerships with property advisors elsewhere in Europe. In 1993 Debenham Tewson \& Chinnocks (now Cushman \& Wakefield) entered into an agreement with Jean Thouard in France and the Zadelhoff Group in Germany and the Netherlands to create the European joint venture DTZ. Other firms had longer-standing relations, such as Richard Ellis (now CBRE), which was first established in France in 1969. London-based firms have also developed glocal networks by means of forming alliances with independent real estate advisors, such as Gerald Eve's work with the Paris-based Estate Consultant.

11 Research by Lizieri, ${ }^{31}$ and Lizieri and Pain ${ }^{32}$ highlights what turned out to be investors' failed attempts to diversify their property portfolios by investing in international financial centres. By virtue of the financialisation of property - wherein "the distinction between the funding of real estate development, ownership of real estate as an investment and occupation of property have become blurred" 33 - property investment is subject to systemic risk "as shocks in one area of the property market are transmitted throughout the system." ${ }_{34}$ This is particularly severe in the case of world financial centres, where a lockstep process simultaneously involving financial firms as occupiers, investors and source of development finance reinforces positive and negative shocks, such that "the amplitude of cyclical fluctuations in IFCs [international financial centres] will be higher and peaks and troughs will be coincident." ${ }^{35}$ Between 2007 and 2011 over $40 \%$ of office investment transactions by volume took place in just ten cities (including London and Paris), each of which is classified as a global financial centre. ${ }^{36} \mathrm{Far}$ from diversifying their property portfolios, following the global world financial crisis investors continued to focus on a limited number of what - on the basis of these markets' maturity and transparency they perceived to be safe havens. Unwittingly perhaps, the Financial Times had already pointed to this in 2007 with its image of recognisable buildings from global financial centres concentrated on one island.

12 An appreciation of how the financialisation of property has created systemic risk, and its more severe impact on world financial centres, has led property researchers to monitor an increasing number of variables determining risk and performance across an increasing number of global financial cities. In its 2019 report JLL and the Business of Cities, members of the company's Global Research Programme and its Business of Cities division assessed 88 global cities across 500 variables, resulting in a six-fold typology: established world cities (comprising the big seven - including London and Paris - and the contenders) new world cities, emerging world cities, hybrids, and national growth centres. ${ }^{37}$ Cushman \& Wakefield's report of the same year, monitored 50 'growth cities' in terms of investment activity and predictions for 2020, ${ }^{38}$ while CBRE Research reported on over 200 global cities by way of its global application ERIX. ${ }^{39}$ Although the number of global cities monitored has increased, much like the idea behind the image used by the Financial Times, these reports and applications construct a representation of 'world business in one place' or - more correctly - a type of world of business in one type of place. At the same time as international firms of property consultants present a 
globalised world of property investment they also cut this world up into countries, cities and property sectors, each of which are either included or excluded. Their research reports, by creating meaning, have performative effects on their audience. By portraying offices in global cities as a source of security - bordered-off together on their island economy - these reports shape the way in which investors (and we their clients) think about the work that property does. Nedelsky points to the way in which this type of representation can be a problem: "Our focus on boundary turns our attention away from relationships and thus away from the true sources and consequences of the patterns of power that property constitutes." ${ }^{40}$ In the following section attention will be turned to the reports addressing the opportunities for investment in offices in Paris and London in the context of Brexit as published by the three leading firms of property consultants.

\section{Property consultants' selling of two cities}

13 The following analysis is based on reports and press articles archived by CBRE, JLL and Cushman \& Wakefield, and available online from the companies' websites. ${ }^{41}$ Since the result of the referendum in 2016 each of the companies has published a small number of reports specifically dealing with Brexit or closely related events in UK politics, such as the snap 2017 general election, (CBRE 4, JLL 1 and Cushman \& Wakefield 8). Brexit featured in a far higher number of reports which were not specifically focussed on the matter (CBRE 26, JLL 16, Cushman \& Wakefield 21), including reports on offices (CBRE 10, JLL 9, Cushman \& Wakefield 1). Brexit was the main topic of a number of press articles or press releases (JLL 8, Cushman \& Wakefield 11, most CBRE reports are accompanied by a press release), and blog posts (CBRE 7; JLL including its UK, French and CEO's blog 17; and Cushman \& Wakefield 5 posts on its Europe Middle East Africa blog). London and Paris were the main subjects of 12 reports published since the referendum, only one of which focussed specifically on Paris. Out of the total of 112 reports, press releases and blog posts which made reference to Brexit, almost half (48) took the form of regular scheduled reports. The timing of the other 64 publications with the exception of five commentaries around the time of the referendum - did not have a close correspondence with key events in the unfolding of the Brexit story. The vote in favour of leaving the EU was not anticipated by the leaders of the property industry. ${ }^{42}$ In the aftermath of the referendum, the firms of consultants were able to draw on the climate of uncertainty and its muted impact on property market fundamentals in order to steer them through the unchartered waters of the political events of the withdrawal process. In order to do this, they positioned their glocal knowledge alongside that of economic advisors and other property market analysts in their reports and commentaries.

In a blog post, the title of which translates as 'The Quarter of La Défense: new towers to welcome the Brexit impatriates', ${ }^{43}$ JLL France drew on an article published in the Financial Times ${ }^{44}$ of the same year in order to present Paris as an office location for firms leaving London consequent on Brexit. Using the Financial Times as its source, as opposed to the French sources on which the FT article was based, it was stated that seven office blocks totalling 375,000 square meters would be built at La Défense by 2021. In its choice of source JLL France avoided reference to campaigns aimed at promoting Paris as an alternative location; while grounds for criticism that it was jumping on the Brexodus bandwagon in order to promote Paris were further weakened by the short 
blog post twice mentioning that Paris would be in competition with other office centres such as Dublin, Frankfurt and Luxemburg.

The firms of consultants could not ignore any possible threat Brexit posed to London's position in the top tier of world financial centres. However, the uncertainty surrounding important issues such as the possible loss of passporting rights ${ }^{45}$ opened the way to scenario-building "in a world of certain uncertainties" ${ }^{46}$ The immediate response to the unanticipated outcome of the referendum was one of wait-and-see, or at least one of wait while the firms of consultants assessed market sentiment. The report published by Cushman \& Wakefield soon after the result of the referendum and with reference to Brexit's impact in Europe, the Middle East and Africa (EMEA), focuses primarily on London. The photographic illustrations were mainly of iconic historic buildings in London (Tower Bridge, Westminster Palace and Regent Street), complete with signature red double decker buses. Although Paris is mentioned as one among a number of "potential winners" in Europe, this would be in the context of a possible "contagion effect" of Brexit, with the report arguing that: "The referendum result clearly brings a significant downside risk not just for the UK but also for the rest of Europe and beyond". ${ }^{47} \mathrm{~A}$ discourse of world financial centres was used in order to point to a bright future for London: "London could still be a winner overall, able to stand alone as an independent financial megacity: Singapore of the north perhaps, continuing to rival New York as the foremost global hub market". ${ }^{48}$ In order to back this argument the report draws on the idea of "the fundamentals of location and what makes it work for business". ${ }^{49}$ This is a refinement of the discourse of world financial centres, in which attention is steered away from the flows of investment that link these cities in order to address what happens in individual locations. Part of the history of all three firms of consultants includes their forbearers having lobbied for London as a world financial centre on the grounds of its unique package of locational advantages..$^{50}$ These advantages have traditionally included such things as its: relative size and ease of doing business, role as a centre for venture capital, infrastructure, strategic lead and concentration of global talent, particularly in financial services. More recently, and not least given that London's concentration of financial services made it particularly vulnerable during the 2008 financial crisis, firms of consultants have added other factors - including culture, innovation and governance - to London's locational attributes (see below). In a backlash to speculation about Brexodus, CBRE highlighted locational fundamentals in arguing a case for London's future: "A lot of column inches are wasted speculating on possible relocations away from London, but much less on what new types of... business might fill the gap". ${ }^{51}$ London as a future hub for financial service firms in insurance and fintech, technology firms and life science firms is for CBRE a key structural influence distinguishing London from its competition.

16 In a research commentary entitled Brex and the City, CBRE takes its reasoning on structural factors further into the future by means of comparing the long-run economic forecasts for the UK economy of thirteen of the leading authorities. It finds that in the likelihood that the UK experiences a significant economic downturn in the next 20 years (the last two downturns having occurred at 18-year intervals): "in 20 years (2040) it seems quite likely that Brexit will be only one of a number of factors affecting the fortunes of British cities - and their real estate". ${ }^{52}$ This reasoning affords CBRE the space to develop its argument that over the long term culture, innovation and governance will be the key location variables. ${ }^{53}$ 
17 Eighteen months on from the referendum, market sentiment found expression in 'London (taking) New York's crown as the leading city for global real estate investment in 2017', as the city experienced a Brexit bounce. ${ }^{54}$ Over the short-term the impact of Brexit on London had been unexpectedly positive, while the impact on Paris received little attention beyond reports of generally small-scale relocations from London to Paris. The volatility of the market, however, soon found expression in a report on CBRE's third quarter 2019 investment survey: 'la capitale française a détrôné la britannique'. ${ }^{55}$ In the face of uncertainty and volatility, the firms of consultants presented a long-term scenario in which global financial centres such as London and Paris would depend on their locational attractiveness, and in which Brexit would be a minor factor in the unfurling of 15-20 year-long property cycles. Given other factors such as how effectively the built environment will adapt in the face of the climate crisis, how new technologies such as robotics and AI will impact on demand for property, and the questionable sustainability of the debt-driven financialisation of property - the consultants' downplaying of the importance of Brexit for both Paris and London over the long term is understandable.

\section{Conclusion}

18 Within a global network of office centres, London and Paris occupy a position on the island economy of world financial centres. At the same time as the financialisation of real estate makes such centres subject to systemic risk, real estate consultants' use of glocal knowledge presents these centres as relatively transparent and secure. This discourse serves among other things to make the borders and filtering process through which capital investment is concentrated on the island economy seem natural. The overview of research reports and market commentaries identified some of the main arguments used by three firms of international property consultants following the unexpected Leave result in the 2016 referendum. The backdrop to scenario-building focussed on the uncertain character of state borders and its implications for investors and occupiers over the short-term. Over the longer-term, the importance of Brexit was discounted and the locational attributes of Paris and London were presented as more important determinants of office market performance in the economic cycle. Symbolic bordering - in, for example, the use of images of historic London or a threat of Brexodus - gave way to more positive attitudes about the locational attributes of both centres in a normative neo-liberal discourse.

One extension of the research presented in this paper would involve bringing together arguments about the discourse of property consultants in constructing borders to property investment and the everyday social relations of: $i)$ the members of teams of researchers compiling these reports, and ii) the surveyors charged with selecting specific properties to match the criteria of secure investment. This paper's description of the development of property consultancy services out of partnerships of chartered surveyors in London is a small step in this direction. Further bottom-up research would provide a better understanding of the 'recursive relationship between actors and markets', as recommended to the property industry 20 years ago. ${ }^{56}$ It would also help in understanding the processes of valuation by which the built environments of cities such as London and Paris are produced, thereby shedding further light on the rarely questioned normative values of property investment. 


\section{BIBLIOGRAPHY}

Ambrose, Peter \& Colenutt, Bob, The Property Machine (London: Penguin, 1975).

Baum, A., Crosby, N., Gallimore, P., Gray, A. \& McAllister, P., The Influence of Valuers and Valuations on the Workings of the Commercial Property Market, Report for the Education Trusts of IPF, RICS and JLL, 2000, London.

Castells, M., The Rise of the Network Society (Oxford: Blackwell, 1996).

CBRE <https://www.cbre.com/research-and-reports/about-cbre-research> [consulted 29th October 2019].

CBRE Real Estate Blog 'London: What are the structural influences on the current property market cycle?' 21st March 2018, <https://aboutrealestate.cbre.eu/> [consulted 6th November 2019].

Counter Information Services Your Money and Your Life: insurance companies and pension funds, (London: CIS, Anti-Report No. 7, January 1974).

Cruise, S. \& Sims, T., 'Bankfurt, Paris await Brexit Boom as Banks Stay Loyal to London', 31st January 2019, <https://www.reuters.com/article/us-britain-eu-bankjobs/> [consulted 8th November 2019].

Cushman \& Wakefield, Brexit \& the European Property Investment Market (London: Cushman \& Wakefield, July 2016).

Cushman \& Wakefield, Winning in Growth Cities 2019/20 (London: Cushman \& Wakefield, October 2019).

D'Arcy, E., 'The Evolution of Institutional Arrangements to Support the Internationalisation of Real Estate Involvements', Journal of European Real Estate Research, 2(3) (2009), pp. 280-293.

De Magalhaes, C. S., 'International Property Consultants and the Transformation of Local Markets', Journal of Property Research, 18(1) (2001), pp. 99-121.

'Editorial Russell Schiller: an Appreciation', Journal of Property Research 22: 2-3 (2006) pp. 61-62.

Feenan, R. (ed.), The Honor Chapman Report: London 1991-2021, The Building of a World City, (London: Jones Lang Lasalle, 2012).

Harvey, D., Social Justice and the City (Oxford: Blackwell, 1988).

Houtum, H. van \& Naerssen, T. van, 'Bordering, Ordering, and Othering', Journal of Economic and Social Geography, 93: 2 (2002) pp. 125-136.

Ireland C., 'JLL UK's Property Predictions' January $2017<$ http://ceoblog.jll.co.uk/> [consulted $2^{\text {nd }}$ November 2019].

JLL France, 'Quartier de le Défense : de nouvelles tours pour accueillir les impatriés du Brexit' $13^{\text {th }}$ November 2017 <https://immobilier.jll.fr/> [consulted $2^{\text {nd }}$ November 2019].

Jones Lang LaSalle, JLL and the Business of Cities, 2019 (London: JLL, 2019)

Keogh, G. and D’Arcy, E., 'Market Maturity and Property Market Behaviour: a European

Comparison of Mature and Emergent Markets', Journal of Property Research, 11 (1994), pp. 215-235.

Lizieri, C., Towers of Capital: Office Markets and International Financial Services (Oxford: BlackwellWiley, 2009). 
Lizieri, Colin, Reinert, J. and Baum, Andrew, Who Owns the City 2011? Change and global ownership of City of London offices (Cambridge: Department of Land Economy, University of Cambridge, 2011).

Massey, Doreen and Catalano, Alejandrina, Capital and Land: landownership by capital in Great Britain (London: Edward Arnold, 1978).

Moran, Michael, The Politics of the Financial Services Revolution: the USA, the UK and Japan (Basingstoke: Macmillan, 1991).

Mortished, C., 'Consultancy Wars' Estates Gazette, Issue 9140 (12th October 1991) p. 70.

Nedelsky, J., 'Law, Boundaries, and the Bounded Self', Representations, 30, 1990, pp. 162-189

Pearson "Financial Times unveils global refresh" $23^{\text {rd }}$ April 2007, archived at: <https:// web.archive.org/web/20131015160110/http://www.pearson.com/> [consulted $22^{\text {nd }}$ October 2019]

Popescu, G., Bordering and Ordering the Twenty-first Century: Understanding Borders (Maryland: Rowman \& Littlefield, 2011).

Sheppard, F. H. W. (ed.), Survey of London 1980, London: London County Council, vol. 39 pp. 11-12 and vol. 40 pp. 33-35). British History Online <http://www.british-history.ac.uk/> [consulted 25th October 2019]

Society of Property Researchers <https://www.sprweb.com> [consulted 30th October 2019]

Sowels, N., 'Brexit and the UK-Based Financial Services', Revue Française de Civilisation Britannique, XXII: 2 (2017).

Sowels, N., 'Brexit and Financial Services: The Major Sticking Points', L'Observatoire de la Société Britannique, 24 (2019).

U.S. Securities and Exchange Commission, Jones Lang LaSalle Incorporated 2018 Form 10-K Annual Report (Washington: U.S. Securities and Exchange Commission, 2019) <https://www.sec.gov/ Archives $>$ [consulted $27^{\text {th }}$ October 2019]

U.S. Securities and Exchange Commission, CBRE Group, Inc. 2018 Form 10-K Annual Report, (Washington: U.S. Securities and Exchange Commission, 2019) <https://ir.cbre.com/financialsinformation/> [consulted 27th October 2019].

U.S. Securities and Exchange Commission, Cushman \& Wakefield plc 2018 Form 10-K Annual Report (Washington: U.S. Securities and Exchange Commission, 2019) <http://ir.cushmanwakefield.com/ financials/ $>$ [consulted 27th October 2019]

Zhu, Bing and Lizieri, Colin 'Connected Markets through Global Real Estate Investments' $<$ https://www.reri.org/research/files/Zhu_Lizieri.pdf> n.d. [consulted 24th October 2019]

\section{NOTES}

1. Sinead Cruise \& Tom Sims 'Bankfurt, Paris await Brexit Boom as Banks Stay Loyal to London', 31st January $2019<$ https://www.reuters.com/> [consulted 8th November 2019].

2. In border studies, the notion of 'bordering' refers to a general understanding of borders as something continually being made. See Henk van Houtum \& Ton van Naerssen'Bordering, Ordering, and Othering', Journal of Economic and Social Geography, 93: 2 (2002) pp. 125-136.

3. On global networks see Manuel Castells The Rise of the Network Society (Oxford: Blackwell, 1996).

4. For a discussion of globalisation's border processes and the limits of state-territory approaches see Gabriel Popescu Bordering and Ordering the Twenty-first Century: Understanding Borders (Maryland: Rowman \& Littlefield, 2011). 
5. David Harvey Social Justice and the City (Oxford : Blackwell, 1988)

6. 'Place-making' refers to ongoing processes of differentiating social space.

7. 'Financialisation of real estate' refers to financial institutions switching from indirect investment through the provision of development finance, to becoming direct investors in property.

8. Counter Information Services Your Money and Your Life: insurance companies and pension funds, London: CIS, Anti-Report No.7, January 1974. See also chapter 6 of Doreen Massey and Alejandrina Catalano Capital and Land: landownership by capital in Great Britain (London: Edward Arnold, 1978).

9. Peter Ambrose and Bob Colenutt The Property Machine (London: Penguin,1975 p. 38)

10. Ibid. p. 41 This range of actors points to the difficulty of assessing the impact of Brexit on office employment, which goes beyond employment in terms of office occupiers to include employment in development, investment and finance (see the section on Brexodus below).

11. Ibid. p. 59

12. For the details of financial sector reform up to and including Big Bang, see Michael Moran The Politics of the Financial Services Revolution: the USA, the UK and Japan (Basingstoke: Macmillan, 1991)

13. Coline Lizieri, Jan Reinert and Andrew Baum Who Owns the City 2011? Change and global ownership of City of London offices (Cambridge: Department of Land Economy, University of Cambridge ,2011).

14. Bing Zhu and Colin Lizieri "Connected Markets through Global Real Estate Investments" $<$ https://www.reri.org/research/files/Zhu_Lizieri.pdf> n.d. [consulted 7th November 2019].

15. Pearson "Financial Times unveils global refresh" (23rd April 2007, archived at <https:// web.archive.org/web/20131015160110/> [consulted 22nd October 2019].

16. The term most likely has it origins in reference to the Mount Coffee House on Grosvenor Street, the master of which witnessed the signing of leases for the early development of the Grosvenor Estate. Although the Estate Board opposed commercial uses on Grosvenor Street, the location developed as the home of chartered surveying partnerships from 1936, when the partnership Hillier, Parker, May and Rowden received approval for its new premises. Sheppard, F.H.W. (ed.), Survey of London (1980, London: London County Council, vol. 39 pp. 11-12 and vol. 40 pp. 33-35).

17. DTZ was formed in 1993 by the merger of Debenham, Tewson \& Chinnocks (UK), Jean Thouard (France) and Zadelhoff (the Netherlands).

18. U.S. Securities and Exchange Commission, Jones Lang LaSalle Incorporated 2018 Form 10-K Annual Report (Washington: U.S. Securities and Exchange Commission, 2019) <https://www.sec.gov/ Archives/>[consulted 27th October 2019] p. 1.

19. U.S. Securities and Exchange Commission, CBRE Group, Inc. 2018 Form 10-K Annual Report (Washington: U.S. Securities and Exchange Commission, 2019) <https://ir.cbre.com/financialsinformation/> [consulted 27th October 2019] p. 1.

20. U.S. Securities and Exchange Commission, Cushman \& Wakefield plc 2018 Form 10-K Annual Report (Washington: U.S. Securities and Exchange Commission, $2019<\mathrm{http}$ ://ir.cushmanwakefield.com/ financials/> [consulted 27th October 2019] p. 3 .

21. The European arms of the research teams of JLL, CBRE and Cushman \& Wakefield are headquartered close to the firms' origins in the coffee houses of the West End of London.

22. Geoffrey Keogh and Eammon D'Arcy 'Market Maturity and Property Market Behaviour: a European Comparison of Mature and Emergent Markets', Journal of Property Research, 11 (1994), pp. 215-235.

23. D’Arcy, E. 'The Evolution of Institutional Arrangements to Support the Internationalisation of Real Estate Involvements', Journal of European Real Estate Research, 2(3) (2009), pp. 280-293. De Magalhaes, C. S. 'International Property Consultants and the Transformation of Local Markets', Journal of Property Research, 18(1) (2001), pp. 99-121. 
24. 'Editorial Russell Schiller: an Appreciation', Journal of Property Research 22: 2-3 (2006) pp. 61-62. 25. Carl Mortished ‘Consultancy Wars' Estates Gazette Issue 9140 (12th October 1991) p. 70.

26. Property research journals include: Journal of Property Research, Journal of Real Estate Research, Journal of European Real Estate Research. Property research is also published in academic journals appealing to a wider audience including: Regional Studies, Urban Studies, Transactions of the Institute of British Geographers, Articulo : Journal of Urban Research, etc.

27. Conferences include: European Real Estate Society Annual Conference (1994 to date), 30th Anniversary Conference of the Society of Property Researchers 2017, Investment Property Forum Inaugural Property Investment Conference 2020.

28. Chairs and professorships include those created by: ESSEC Business School, Henley Business School, University of Cambridge, Saïd Business School and Cass Business School.

29. Society of Property Researchers <https://www.sprweb.com/> [consulted 30th October 2019].

30. Eric Swyngedouw 'Neither Global nor Local: "Glocalization" and the Politics of Scale', in K. Cox (Ed) Spaces of Globalization: Reasserting the Power of the Local (London: Longman, 1997, pp. 137-166).

31. Colin Lizieri Towers of Capital: Office Markets and International Financial Services (Oxford: Blackwell-Wiley, 2009).

32. Colin Lizieri and Kathy Pain 'International office Investment in Global Cities : Financial Space and Systemic Risk', Regional Studies 28: 3 (2014) pp. 439-455.

33. Ibid., p. 446.

34. Ibid., p. 446.

35. Ibid., p. 447.

36. Ibid., p. 447.

37. Jones Lang LaSalle JLL and the Business of Cities, 2019 (London: JLL, 2019)

38. Cushman \& Wakefield Winning in Growth Cities 2019/20 (London: Cushman \& Wakefield, 2019).

39. CBRE https://www.cbre.com/research-and-reports/about-cbre-research [consulted 29th October 2019]

40. Jennifer Nedelsky 'Law, Boundaries, and the Bounded Self', Representations, 30, 1990, pp. 162-189.

41. The data analysed in this paper excludes reports commissioned by clients, provided on a subscription basis, and quarterly and half yearly reports which are removed from the archive once they cease to be current.

42. Prior to the referendum, a show of hands at a meeting of 400 leaders of the property industry found that $80 \%$ thought that the UK would vote to Remain in the UK. 'JLL UK's Property Predictions' January 2017 <https://ceoblog.jll.co.uk/> [consulted 2nd November 2019].

43. JLL France 'Quartier de le Défense : de nouvelles tours pour accueillir les impatriés du Brexit' 13th November 2017 <https://immobilier.jll.fr> [consulted 2nd November 2019].

44. Stothard, M. 'Paris Attempts to Lure Business from London with New Skyscrapers', Financial Times 22nd February 2017 <https://www.ft.com> [consulted 2nd November 2019].

45. 'Passporting rights' refers to firms operating in one member state having the right to operate in another member state of the European Economic Area (EEA). Many financial services providers in the UK rely on this right to provide products across Europe. Loss of this right would prevent UK-based investment firms providing services to clients in EEA countries. For the impact of Brexit on London's financial services sector in the immediate post-referendum period up to February 2017 see Nicholas Sowels 'Brexit and the UK-Based Financial Services', Revue Française de Civilisation Britannique, XXII: 2 (2017). For the position by late-November 2018 see Nicholas Sowels 'Brexit and Financial Services: The Major Sticking Points', L'Observatoire de la Société Britannique, 24 (2019).

46. Cushman \& Wakefield Brexit \& the European Property Investment Market, July 2016, London: Cushman \& Wakefield. 
47. Ibid. p. 1.

48. Ibid. p. 14.

49. Ibid. p. 14 .

50. A noteable example is the work of Honor Chapman of Jones Lang Wootton, founding CEO of Think London and board member of the London Development Agency. For an overview of her work in promoting London in the face of competition from other world financial centres see osemary Feenan (ed.) The Honor Chapman Report: London 1991-2021, The Building of a World City (London: Jones Lang Lasalle, 2012).

51. CBRE Real Estate Blog 'London: What are the structural influences on the current property market cycle?' 21st March 2018, https://aboutrealestate.cbre.eu/ [consulted 6th November 2019]. 52. CBRE 'Brex and the City?' <https://www.cbre.fr/> n.d. [consulted 6th November 2019]

53. CBRE 'What Makes a Successful City?' October 2018, <https://news.cbre.co.uk/> [consulted 6th November 2019].

54. JLL 'London Calling: UK Capital Top for Real Estate Investment in 2017', 25th January 2018 $<$ https://www.theinvestor.jll/>[consulted 6th November 2019].

55. Boccara, L. 'Immobilier : les investisseurs étrangers préfèrent Paris à Londres', Les Echos, 8th November 2019, https://www.lesechos.fr/ [consulted 10th November 2019].

56. Baum, A. et al. The Influence of Valuers and Valuations on the Workings of the Commercial Property Market (London: Report for the Education Trusts of IPF, RICS and JLL, 2000).

\section{ABSTRACTS}

This paper draws on recent conceptual work in the field of border studies in order to analyse the island economy - of which London and Paris are a part - as a dynamic functional process of bordering. The particular focus is on the commercial real estate markets of the two cities, and the discourse of firms of international property consultants. It is shown that these non-state actors play a key role in standardising information so that investors perceive the office markets of global cities as transparent. A brief account is given of the evolution of these cross-border consultancy relations since Big Bang in 1986 and in the context of the financialisation of real estate. The paper then goes on to examine research reports and commentaries published since the 2016 United Kingdom European Union membership referendum by the three leading firms of property consultants covering the London and Paris office markets. This was a period marked by much speculation about the transfer of jobs (Brexodus) in financial services from London to Paris. For international investors in real estate, Brexit added a new variable to their calculations of risk, and one that seemingly muddied the waters of the relatively transparent property markets of London and Paris. The analysis of market commentaries concludes that the international network of glocal property consultants plays a role in the on-going process of bordering and filtering flows of finance that reflect the normative power of international real estate investors.

Cet article s'inspire de travaux conceptuels récents dans le domaine des études sur les frontières afin d'analyser the island economy - dont Londres et Paris font partie - à la suite d'un processus fonctionnel dynamique de délimitation des frontières. L'accent est mis sur les marchés immobiliers commerciaux des deux villes et sur le discours des firmes de consultants immobiliers internationaux. Il émerge que ces acteurs non étatiques jouent un rôle clé dans la standardisation 
de l'information, afin que les investisseurs perçoivent les marchés de bureaux des villes mondiales comme transparents. Nous présentons l'évolution de ces relations de conseil transfrontalières depuis le Big Bang en 1986 et dans le contexte de la financiarisation de l'immobilier. Nous analysons ensuite les rapports de recherche et les commentaires publiés depuis le référendum sur Brexit en 2016 par les trois principales sociétés de conseil en immobilier couvrant les marchés des bureaux à Londres et à Paris. C'est une période marquée par de nombreuses spéculations sur le transfert d'emplois (Brexodus) dans les services financiers de Londres à Paris. Pour les acteurs internationaux dans l'immobilier, le Brexit a ajouté une nouvelle variable à leurs calculs de risque, une variable qui a apparemment brouillé les cartes du marché immobilier relativement transparent de Londres et de Paris. De notre analyse émerge que ces glocal entreprises jouent un rôle dans un processus en cours de bordering et de filtrage des flux de financement reflétant le pouvoir normatif des investisseurs immobiliers internationaux.

\section{INDEX}

Mots-clés: Brexodus, bordering, global-local, Paris, Londres, consultants immobiliers internationaux, investissement immobilier

Keywords: Brexodus, bordering, global-local, Paris, London, international property consultants, property investment

\section{AUTHOR}

\section{SUSAN BALL}

TransCrit (EA1569), Université Paris 8.

Susan Ball is Senior Lecturer in Contemporary British Civilisation at the University of Paris 8. Her main areas of research are land use planning policy, property research, career migration and socio-spatial relations. 